Article

\title{
$\alpha$-Tocomonoenol Is Bioavailable in Mice and May Partly Be Regulated by the Function of the Hepatic $\alpha$-Tocopherol Transfer Protein
}

\author{
Andrea Irías-Mata ${ }^{1}{ }^{1}$, Nadine Sus ${ }^{1}$, Maria-Lena Hug ${ }^{1}$, Marco Müller ${ }^{2}$, Walter Vetter ${ }^{2}$ and \\ Jan Frank 1,*(D) \\ 1 Department of Food Biofunctionality, Institute of Nutritional Sciences, University of Hohenheim, \\ Garbenstr. 28, D-70599 Stuttgart, Germany; andrea.iriasmata@ucr.ac.cr (A.I.-M.); \\ nadine.sus@nutres.de (N.S.); maria-lena.hug@gmx.de (M.-L.H.) \\ 2 Institute of Food Chemistry, University of Hohenheim, D-70599 Stuttgart, Germany; \\ marcomueller17@t-online.de (M.M.); walter.vetter@uni-hohenheim.de (W.V.) \\ * Correspondence: jan.frank@nutres.de; Tel.: +49-711-459-24459; Fax: +49-711-459-23386
}

Academic Editors: Tuba Esatbeyoglu, Banu Bayram and Adele Papetti

Received: 4 September 2020; Accepted: 15 October 2020; Published: 19 October 2020

\begin{abstract}
Tocomonoenols are vitamin E derivatives present in foods with a single double bond at carbon $11^{\prime}$ in the sidechain. The $\alpha$-tocopherol transfer protein (TTP) is required for the maintenance of normal $\alpha$-tocopherol $(\alpha \mathrm{T})$ concentrations. Its role in the tissue distribution of $\alpha$-11'-tocomonoenol $\left(\alpha \mathrm{T}_{1}\right)$ is unknown. We investigated the tissue distribution of $\alpha \mathrm{T}_{1}$ and $\alpha \mathrm{T}$ in wild-type $\left(\mathrm{TTP}^{+/+}\right)$and TTP knockout $\left(\mathrm{TTP}^{-/-}\right)$mice fed diets with either $\alpha \mathrm{T}$ or $\alpha \mathrm{T}_{1}$ for two weeks. $\alpha \mathrm{T}_{1}$ was only found in blood, not tissues. $\alpha \mathrm{T}$ concentrations in $\mathrm{TTP}^{+/+}$mice were in the order of adipose tissue $>$brain $>$ heart $>$ spleen $>$ lungs $>$ kidneys $>$ small intestine $>$ liver. Loss of TTP function depleted $\alpha \mathrm{T}$ in all tissues. $\alpha \mathrm{T}_{1}$, contrary to $\alpha \mathrm{T}$, was still present in the blood of $\mathrm{TTP}^{-/-}$mice $\left(16 \%\right.$ of $\alpha \mathrm{T}_{1}$ in $\left.\mathrm{TTP}^{+/+}\right)$. Autoclaving and storage at room temperature reduced $\alpha \mathrm{T}$ and $\alpha \mathrm{T}_{1}$ in experimental diets. In conclusion, $\alpha \mathrm{T}_{1}$ is bioavailable, reaches the blood in mice, and may not entirely depend on TTP function for secretion into the systemic circulation. However, due to instability of the test compounds in the experimental diets, further in vivo experiments are required to clarify the role of TTP in $\alpha \mathrm{T}_{1}$ secretion. Future research should consider compound stability during autoclaving of rodent feed.
\end{abstract}

Keywords: $\alpha$-tocopherol transfer protein (TTP) knockout mice; $\alpha$-tocomonoenol; adipose tissue; blood; liver; depletion; vitamin E

\section{Introduction}

The vitamin E family comprises eight structurally-related lipid-soluble compounds composed of a chromanol ring attached to a saturated (tocopherols $(T)$ ) or threefold unsaturated (tocotrienols) 16-carbon sidechain, with the prefixes $\alpha, \beta, \gamma$, or $\delta$ designating the number and position of methyl groups substituted at the chromanol ring [1]. $\alpha-11^{\prime}$-Tocomonoenol ( $\alpha$ T1; Figure 1), a novel vitamin E derivative with the structural feature of a single double bond at carbon $11^{\prime}$, was reported for the first time in 1995 [2] and later detected in palm, pumpkin, and sunflower oils [3-5].

From the gastrointestinal tract, all eight vitamin E congeners are absorbed and transported to the liver in a similar extent, but then the liver selectively secretes $\alpha$-tocopherol $(\alpha \mathrm{T})$ into the bloodstream for distribution in the body, whereas the non- $\alpha \mathrm{T}$ forms are preferentially metabolized via a cytochrome $\mathrm{P}_{450}$-dependent pathway [6]. It has been suggested that the selective retention of $\alpha \mathrm{T}$ is the result of an interaction of the catabolic pathway with the hepatic $\alpha$-tocopherol transfer protein (TTP) [7]. This is a cytosolic protein that preferentially binds $\alpha \mathrm{T}(100 \%)$ over the other congeners, $\beta$-tocopherol $(38 \%)$, 
$\gamma$-tocopherol (9\%), $\delta$-tocopherol (2\%), and $\alpha$-tocotrienol (12\%) [8]. TTP is expressed primarily in the liver, but it has also been detected in other tissues, such as the rat brain, spleen, lung, kidney [9], rat uterus [10], and eye retina [11], suggesting that its expression in other organs regulates distinct tissue-specific accumulations of the vitamin [12].<smiles>Cc1c(C)c2c(c(C)c1O)CCC(C)(CCCC(C)CCCC(C)CCCC(C)C)O2</smiles><smiles>CC(C)=CCCC(C)CCCC(C)CCCC1(C)CCc2c(C)c(O)c(C)c(C)c2O1</smiles>

Figure 1. Chemical structures of $\alpha$-tocopherol and $\alpha$-11'-tocomonoenol.

Humans with mutations in the Ttpa gene encoding TTP develop ataxia with vitamin E deficiency (AVED) and are unable to maintain normal $\alpha \mathrm{T}$ plasma concentrations [6,12]. Previous studies regarding the tissue distribution of $\alpha \mathrm{T}$ alone or in combination with their homologues all-rac- $\alpha \mathrm{T}, \alpha$-tocotrienol, $\gamma$-tocopherol, and $\gamma$-tocotrienol reported a wide distribution of $\alpha \mathrm{T}$ in blood and tissues, primarily in the liver, lungs, spleen, and brain. The deletion of the Ttpa gene in mice (TTP knockout mice) leads to the depletion of $\alpha \mathrm{T}$ from all tissues [7,13-22].

The uptake of dietary $\alpha \mathrm{T}_{1}$ and its tissue concentration has only been studied in a single trial in mice, in which $\alpha \mathrm{T}_{1}$ was detected in the liver and brain [23]. A deeper understanding of the tissue distribution, the accumulation of $\alpha \mathrm{T}_{1}$, and their regulation (possibly by TTP) is required to elucidate its potential to exert the biological activity of vitamin $\mathrm{E}$ in mammals. We therefore investigated the tissue distribution of $\alpha \mathrm{T}_{1}$ and $\alpha \mathrm{T}$ in wild-type and TTP knockout mice (TTP $\left.{ }^{-/-}\right)$following ingestion of the diet for two weeks.

\section{Results and Discussion}

\subsection{Animal Performance}

To investigate the tissue distribution of $\alpha \mathrm{T}_{1}$ and its regulation by TTP, we fed 2-3-month-old wild-type $\left(\mathrm{TTP}^{+/+}\right)$and TTP knockout mice $\left(\mathrm{TTP}^{-/-}\right.$, Figure 2$)$ for two weeks with diets prepared with either $30 \mathrm{mg} / \mathrm{kg} \alpha \mathrm{T}_{1}$ or $\alpha \mathrm{T}$. No significant differences in body weight gain, final body weight, and absolute and relative (adjusted to body weight) organ weights were observed between the experimental groups (data not shown). This indicated a normal, healthy, and comparable performance of the mice during the experiment. 


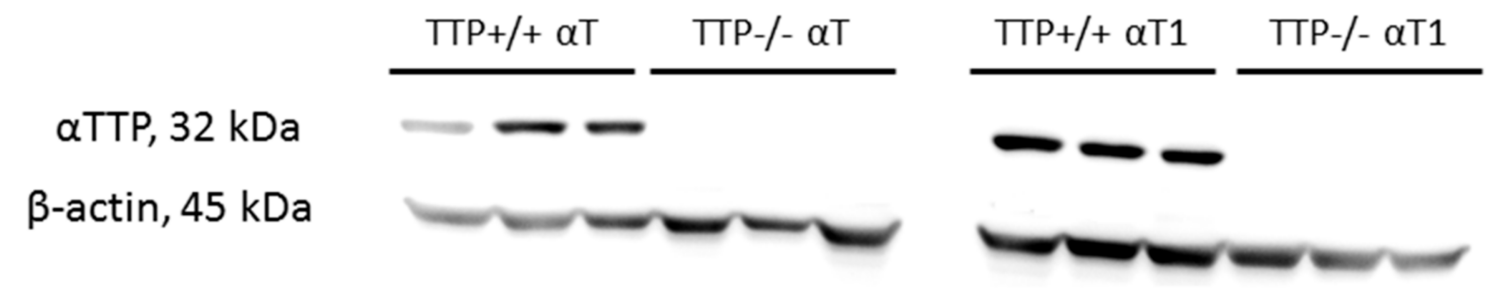

Figure 2. Representative Western blots of hepatic $\alpha$-tocopherol transfer protein (TTP) expression in $\mathrm{TTP}+/+$ and TTP $-/-$ mice $(\mathrm{n}=11)$ used in the feeding trial.

\subsection{Bioavailability of $\alpha \mathrm{T}$ and $\alpha \mathrm{T}_{1}$ in $\mathrm{TTP}^{+/+}$and $\mathrm{TTP}^{-/-}$Mice}

To the best of our knowledge, this is the first time that the presence of $\alpha \mathrm{T}_{1}$ is reported in the blood of $\mathrm{TTP}^{+/+}$and $\mathrm{TTP}^{-/-}$mice (Figure 3 ). In a previous mouse trial, $\alpha \mathrm{T}_{1}$ was found in the liver and brain, but not in the blood [23]. Here, we found no $\alpha \mathrm{T}_{1}$ in tissues, which is in partial agreement with the previous publication, where it was not found in the lung and spleen [23]. The absence of $\alpha T_{1}$ from tissues is likely explained by the low amounts of the compound ingested by our mice (see Section 2.3 for further details).

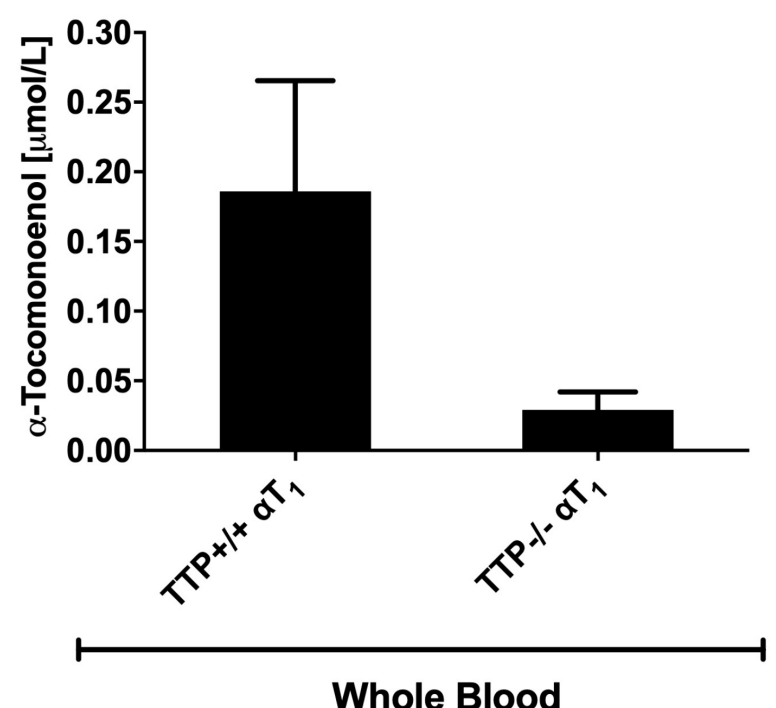

Figure 3. Mean whole blood concentration (error bars represent standard error of the mean; $n=11$ ) of $\alpha-11^{\prime}$-tocomonoenol $\left(\alpha \mathrm{T}_{1}\right)$ in $\mathrm{TTP}^{+/+}$and $\mathrm{TTP}^{-/-}$mice fed a standard diet with either $\alpha$-tocopherol $(\alpha \mathrm{T})$ or $\alpha \mathrm{T}_{1}$ for 2 weeks.

$\alpha \mathrm{T}_{1}$ was numerically reduced in the blood of $\mathrm{TTP}^{-/-}$mice, but contrary to $\alpha \mathrm{T}$ (Figure 4 ), it was still present in the blood (Figure 3). Earlier publications reported a TTP-independent distribution of $\alpha$-tocotrienol into the bloodstream [15]. Nevertheless, our results cannot rule out that TTP is involved in the distribution of $\alpha \mathrm{T} 1$. The observed reduction in $\alpha \mathrm{T}_{1}$ concentrations in the blood of $\mathrm{TTP}^{-/-}$mice suggests that $\alpha \mathrm{T}_{1}$ may not require TTP activity to the same extent as $\alpha \mathrm{T}$ for secretion into the blood (Figure $4 \mathrm{H}$ ), but there may still be a TTP influence on $\alpha \mathrm{T}_{1}$ bioavailability. However, due to problems with the stability of $\alpha \mathrm{T}_{1}$ in the experimental diets (see Section 2.3), these preliminary findings need to be interpreted with caution and require further substantiation by additional experiments. 
A

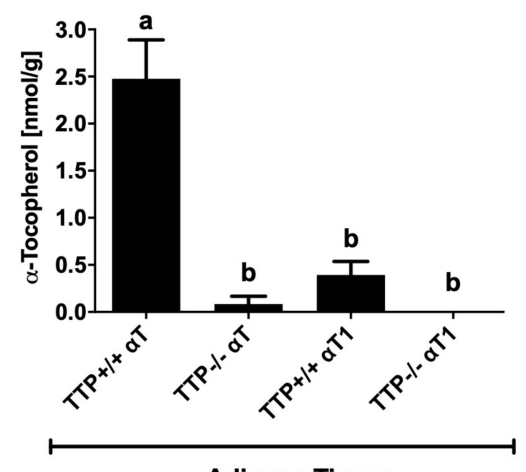

Adipose Tissue

\section{C}
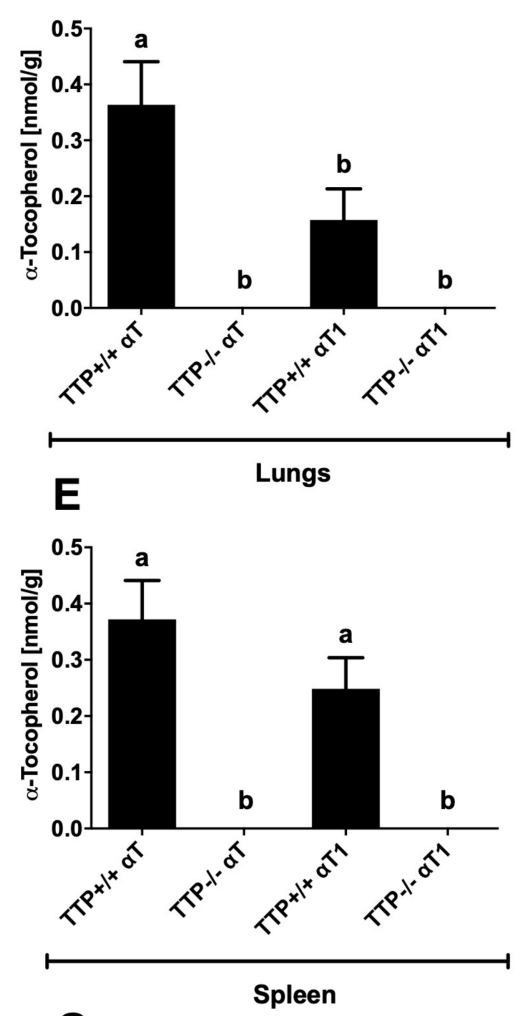

\section{G}

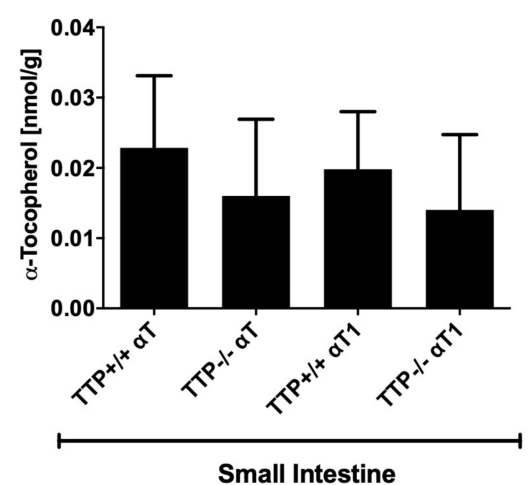

B

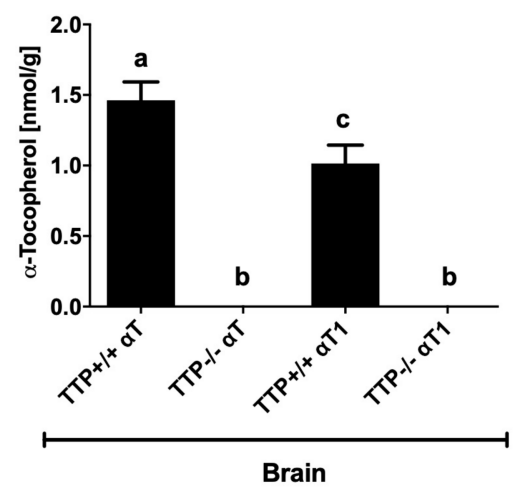

D
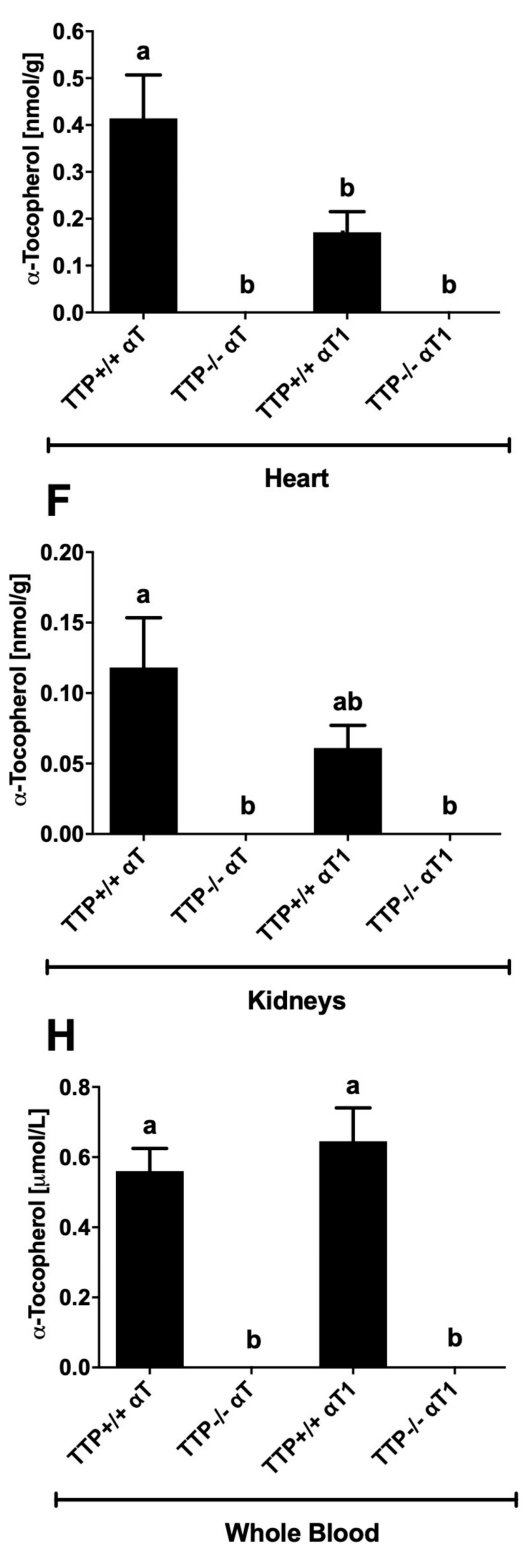

Figure 4. Mean tissue concentrations (error bars represent standard error of the mean; $n=11$ ) of $\alpha$-tocopherol $(\alpha \mathrm{T})$ in (A) adipose tissue, (B) brain, (C) lung, (D) heart, (E) spleen, (F) kidney, (G) small intestine, and (H) whole blood of $\mathrm{TTP}^{+/+}$and $\mathrm{TTP}^{-/-}$mice fed a standard diet with either $\alpha \mathrm{T}$ or $\alpha$-11'-tocomonoenol $\left(\alpha \mathrm{T}_{1}\right)$ for 2 weeks. Bars not sharing a common letter are significantly different at $p<0.05$. 
$\alpha \mathrm{T}$ was present in the blood and all examined tissues, with the exception of the liver, of $\mathrm{TTP}^{+/+}$ mice fed $\alpha \mathrm{T}$ or $\alpha \mathrm{T}_{1}$ (Figure 4). $\alpha \mathrm{T}$ was also present in $\alpha \mathrm{T}_{1}$-fed mice because all animals received $\alpha \mathrm{T}$-containing diets until the beginning of the trial, and the short duration of the trial did not result in a complete depletion of $\alpha \mathrm{T}$ in the tissues. Another potentially contributing process that deserves further investigation is the conversion of $\alpha \mathrm{T}_{1}$ to $\alpha \mathrm{T}$ by sidechain saturation. Earlier investigations reported that the metabolism of tocotrienols involves enzymes, probably 2,4-dienoyl-coenzyme A-reductase, that catalyze the saturation of the sidechain, similar to those involved in the $\beta$-oxidation of unsaturated fatty acids [24]. This sidechain saturation would align with the observed concentrations of $\alpha \mathrm{T}$ in the blood and tissues of $\mathrm{TTP}^{+/+}$mice fed $\alpha \mathrm{T}_{1}$.

$\alpha \mathrm{T}$ concentrations in $\alpha \mathrm{T}$-fed $\mathrm{TTP}^{+/+}$mice were in the order of adipose tissue $>$brain $>$heart $>$ spleen $>$ lungs $>$ kidneys $>$ small intestine $>$ liver and reached $0.560 \pm 0.065 \mu \mathrm{mol} / \mathrm{L}$ in blood (Figure 4). Relatively high $\alpha \mathrm{T}$ concentrations in adipose tissue were reported before $[13,16,25]$ and explained by the comparably low turnover of adipocytes, which slowly accumulated and released $\alpha \mathrm{T}[16,26]$. Adipose tissue was also reported as the main storage for $\alpha$ - and $\gamma$-tocotrienols and marine-derived tocopherol $[14,16,18,25,27]$.

Overall, $\alpha \mathrm{T}$ concentrations in tissues were about 10 -fold lower than the values reported in tissues of mice and rats fed diets containing 30-100 $\mathrm{mg} \alpha \mathrm{T}$ per $\mathrm{kg}$ diet $[7,13,16,18,25]$. These low $\alpha \mathrm{T}$ concentrations in tissues are more similar to values reported in mice and rats after feeding of $\alpha \mathrm{T}$-deficient or $\alpha \mathrm{T}$-free diets $[16,25,28]$. The unexpected depletion of $\alpha \mathrm{T}$ and $\alpha \mathrm{T}_{1}$ from the livers of our mice was confirmed by GC/MS analyses (see Figure S1, data interpretation based on a previous publication [29]). It was previously reported that $\alpha \mathrm{T}$ is secreted from the liver at a higher rate, thus possibly depleting the liver of $\alpha \mathrm{T}$ when the intake of the vitamin is inadequate $[26,30]$. A complete reduction of $\alpha \mathrm{T}$ in the liver was reported for $\mathrm{TTP}^{-/-}$mice fed a vitamin E-depleted diet from the age of 3 to 18 months [31], for male Wistar rats fed a diet containing $<0.4 \mu \mathrm{g} / \mathrm{g} \alpha \mathrm{T}$ for 6 weeks followed by an $\alpha \mathrm{T}$-free diet for 7 days [25], and an almost complete depletion of $\alpha \mathrm{T}$ from the liver was observed in male Fisher 344 rats after 6 months feeding with an $\alpha \mathrm{T}$-deficient diet [32], as well as in male Wistar rats fed a vitamin E-free diet from 6 until 10 weeks old [16], but not in animals fed the recommended dietary dose of $30 \mathrm{mg} / \mathrm{kg}$ feed. The overall low $\alpha \mathrm{T}$ and $\alpha \mathrm{T}_{1}$ values in the tissues and their complete depletion from the liver led us to question the stability of the congeners in the experimental diets and the resulting amounts fed to our mice (see Section 2.3).

As expected, deletion of the Ttpa gene in mice resulted in almost complete depletion of $\alpha \mathrm{T}$ from tissues and blood (Figure 4), highlighting its importance for the maintenance of an adequate $\alpha \mathrm{T}$ status, as previously reported $[7,13,22,29]$. In agreement with our understanding of the role of TTP in mediating the selective secretion of $\alpha \mathrm{T}$ from the liver into the bloodstream [6], $\alpha \mathrm{T}$ concentrations in the small intestine were not under the control of TTP and therefore similar in $\mathrm{TTP}^{+/+}$and $\mathrm{TTP}^{-/-}$mice.

\section{3. $\alpha \mathrm{T}$ and $\alpha T_{1}$ in Experimental Diets}

As mentioned above, the low $\alpha \mathrm{T}$ concentrations in tissues and the depletion of $\alpha \mathrm{T}$ and $\alpha \mathrm{T}_{1}$ from the livers of our mice made us question the stability of both vitamin E congeners in the experimental diets fed to our animals. We therefore retrospectively measured the concentrations of $\alpha \mathrm{T}$ and $\alpha \mathrm{T}_{1}$ in the experimental diets, which were prepared with $30 \mathrm{mg}$ of the respective congener per kilogram diet, but only found $\leq 1 \mathrm{mg} / \mathrm{kg}$ diet (Supplementary Figure S2). In the search of an explanation for this, we hypothesized that a sterilization procedure, such as autoclaving, which was performed on the diets prior to their transfer into the animal facilities, might partly explain the degradation. We therefore autoclaved a standard experimental diet with $30 \mathrm{mg} / \mathrm{kg} \alpha \mathrm{T}$ at $120{ }^{\circ} \mathrm{C}$ for $20 \mathrm{~min}$ and directly extracted for vitamin $\mathrm{E}$ analysis or stored them for one week at room temperature and a $12 \mathrm{~h}$ dark/light cycle before extraction and analysis. We also determined the vitamin E content in the diet before and after one week of storage at the conditions present in the animal facilities during the experiment. We observed a 32\% reduction in $\alpha \mathrm{T}$ after autoclaving, a 39\% reduction after autoclaving and one week of storage, and a $20 \%$ reduction after one week of storage at the housing conditions of the mice 
(Figure 5). We therefore concluded that autoclaving and storage under housing conditions partly contributed to the degradation of vitamin $\mathrm{E}$ in the diets, but it does not entirely explain the massive losses of $\alpha \mathrm{T}$ and $\alpha \mathrm{T}_{1}$. It is also possible that the vitamin-E-free corn oil, in which $\alpha \mathrm{T}$ and $\alpha \mathrm{T}_{1}$ were diluted and then shipped to the manufacturer of the experimental diets for the preparation of our experimental diets, promoted the oxidation of the vitamin E congeners, and that the final concentrations of $\alpha \mathrm{T}$ and $\alpha \mathrm{T}_{1}$ in the diets were therefore significantly lower than planned.

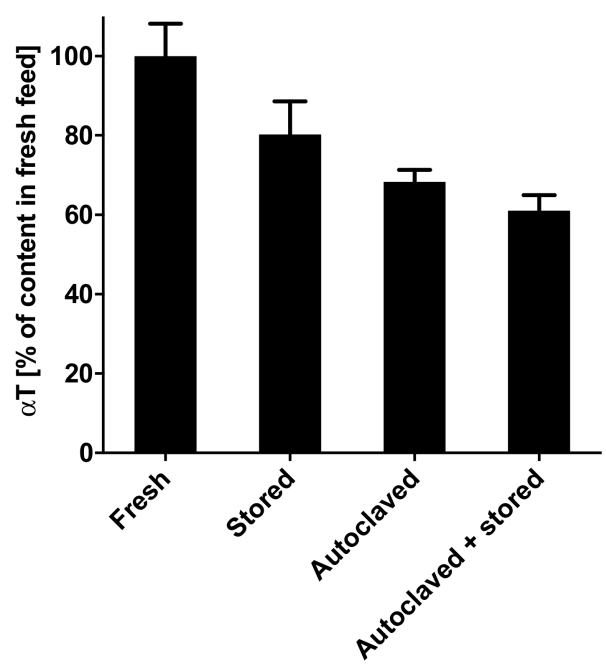

Figure 5. Mean total $\alpha$-tocopherol $(\alpha \mathrm{T})$ content (error bars represent standard error of the mean; $n=3$ ) of stored ( 1 week at room temperature with $12 \mathrm{~h}$ light/dark cycle), autoclaved $\left(20 \mathrm{~min}\right.$ at $\left.121{ }^{\circ} \mathrm{C}\right)$, and autoclaved and stored rodent feed relative to fresh feed (not stored, not autoclaved, directly extracted and analysed). The C1000 rodent feed used was from Altromin Spezialfutter GmbH \& Co (KG, Lage, Germany).

Even though we currently cannot rule out alternative explanations, it is possible that the low intake of $\alpha \mathrm{T}$ in our animals led to a redistribution of $\alpha \mathrm{T}$ from the liver to peripheral tissues, resulting in the observed depletion of vitamin E from this organ and the lower values in the other tissues.

Notably, regardless of the low contents of $\alpha \mathrm{T}$ and $\alpha \mathrm{T}_{1}$ in the experimental diets, the presence of $\alpha \mathrm{T}_{1}$ in blood is promising, as the bioavailability of $\alpha \mathrm{T}_{1}$ is a requirement for further studies into any potential biological activities and health benefits of this dietary compound. The reported content of $\alpha \mathrm{T}_{1}$ in food sources varies, but is generally low. Concentrations similar to those in our experimental diets, namely of $0.08-3.0 \mathrm{mg} / \mathrm{kg}$ [5] and below $10 \mathrm{mg} / \mathrm{kg}$ [4], have been reported for some varieties of palm oil and sunflower oil, respectively.

In conclusion, we report for the first time the absorption of $\alpha \mathrm{T}_{1}$ into the blood of mice. Contrary to $\alpha \mathrm{T}, \alpha \mathrm{T}_{1}$ was still found in the blood of mice not expressing TTP, but at lower concentrations than in wild-type mice. These results suggest that $\alpha \mathrm{T}_{1}$ secretion from the liver may not, or not to the same extent as $\alpha \mathrm{T}$, depend on the function of TTP, but may still be partly controlled by it. However, additional experiments are required to substantiate or refute this.

We further conclude that significant losses of vitamin $\mathrm{E}$ in experimental diets are caused by autoclaving, which is frequently applied prior to the transfer of experimental feeds into specified pathogen-free animal facilities. Such losses need to be considered and concentrations of vitamin $\mathrm{E}$ in feeds should be analytically confirmed prior to using them in animal experiments.

\section{Materials and Methods}

\subsection{Test Compounds and Diets}

RRR- $\alpha$-tocopherol ( $\alpha \mathrm{T}, \geq 95 \%$, CAS number 59-02-9, cat\#KP5101) was from DSM (Grenzach, Germany), and $\alpha-11^{\prime}$-tocomonoenol $\left(\alpha \mathrm{T}_{1} ; \geq 99.5 \%\right.$ pure) was extracted from vitamin $\mathrm{E}$ capsules as 
previously described [30]. $\alpha \mathrm{T}$ and $\alpha \mathrm{T}_{1}$ (165 mg each) were separately dissolved in $1 \mathrm{~mL}$ of ethanol and mixed thoroughly in $275 \mathrm{~g}$ vitamin E-stripped corn oil (Dyets, Bethlehem, PA, USA). The fortified oils were used in the preparation of semisynthetic standard rodent diets (vitamin E free standard diet, C1000; Altromin Spezialfutter, Lage, Germany) containing $5 \%$ oil and $30 \mathrm{mg} / \mathrm{kg}$ of either $\alpha \mathrm{T}$ or $\alpha \mathrm{T}_{1}$.

\subsection{Animal Experiment}

All animal procedures were carried out in accordance with the FELASA guidelines for the care and use of laboratory animals and approved by the Regional Council Stuttgart (Baden-Württemberg, Germany; trial no. V 342/17 BC). Forty-four female mice (2-3 months old, $21.2 \pm 0.6 \mathrm{~g}$ ) from our colony at the University of Hohenheim were fed for two weeks the $\alpha \mathrm{T}$-containing diet before $22 \mathrm{C} 57 \mathrm{BL} / 6$ wild-type mice $\left(\mathrm{TTP}^{+/+}\right)$and 22 homozygous TTP knockout mice $\left(\mathrm{TTP}^{-/}\right.$, genotype confirmed by PCR) were randomized into four groups of 11 mice. Animals from each genotype were fed the experimental diets (modified C1000; Altromin) prepared with $30 \mathrm{mg} / \mathrm{kg}$ of either $\alpha \mathrm{T}$ or $\alpha \mathrm{T}_{1}$ for two weeks. Mice were housed in groups of maximum four per cage in a controlled environment $\left(22 \pm 2{ }^{\circ} \mathrm{C}, 55 \pm 10 \%\right.$ humidity, $12 \mathrm{~h}$ light/dark cycle) and had free access to food and water. After 2 weeks, animals were fasted for $12 \mathrm{~h}$, anaesthetized with $\mathrm{CO}_{2}$, and killed by cervical dislocation. Blood was collected into heparinized tubes, and tissues (small intestine, liver, lungs, heart, kidneys, spleen, adipose tissue, and brain) were excised and snap-frozen in liquid nitrogen. All samples were immediately stored at $-80{ }^{\circ} \mathrm{C}$ until further analysis.

\subsection{HPLC Analysis}

All chemicals used were of the highest purity and purchased from Sigma-Aldrich (Taufkirchen, Germany), JT Baker (Phillipsburg, NJ, USA), or Merck (Darmstadt, Germany). Methanol was HPLCgradient grade and water was deionized and filtered (Millipore, Billerica, MA, USA). $\alpha \mathrm{T}$ and $\alpha \mathrm{T}_{1}$ were extracted from tissues $(200 \mathrm{mg})$ and whole blood $(100 \mu \mathrm{L})$ and saponified as previously described [33]. Prior to HPLC analysis, extracts were re-suspended in $100 \mu \mathrm{L}$ methanol/water $(85: 15, v / v)$ and transferred to amber HPLC vials. Twenty microliters of the extract was injected into a Jasco HPLC (system controller LC-Net II/ADC, two pumps X-LC ${ }^{\mathrm{TM}}$ 3185PU, mixing unit X-LC ${ }^{\mathrm{TM}}$ 3180MX, degasser X-LC ${ }^{\mathrm{TM}}$ 3080DG, autoinjector X-LC ${ }^{\mathrm{TM}}$ 3159AS, column oven X-LC ${ }^{\mathrm{TM}} 3067 \mathrm{CO}$ and fluorescence detector FP-2020 Plus; Jasco, Germany). Test compounds were separated on a Phenomenex Kinetex ${ }^{\mathrm{TM}}$ PFP column $(2.6 \mu \mathrm{m}$ particle size, $150 \times 4.6 \mathrm{~mm})$ maintained at $40^{\circ} \mathrm{C}$ using methanol/water $(85: 15, v / v)$ at a flow rate of $1.7 \mathrm{~mL} / \mathrm{min}$, for a total run time of $15 \mathrm{~min}$. The fluorescence detector was operated at excitation/emission wavelengths of $296 / 325 \mathrm{~nm}$, respectively. Peaks were recorded and integrated using Chrompass software (version 1.9. 302.1124, Jasco) and quantified against external standard curves using the authentic compounds.

\subsection{GC/MS Analysis}

To confirm the presence or absence of $\alpha \mathrm{T}$ and $\alpha \mathrm{T} 1$, crude extracts of liver samples were redissolved in $500 \mu \mathrm{L} n$-hexane, treated by column chromatography for purification, silylated, and analyzed by gas chromatography with mass spectrometry (GC/MS) as previously described [30].

\subsection{Western Blot Analysis of TTP Expression}

Liver protein homogenates were prepared in radioimmunoprecipitation assay buffer (Tris, $50 \mathrm{mM}$; $\mathrm{NaCl}, 150 \mathrm{mM}$; sodium dodecyl sulfate (SDS), $0.1 \%$; sodium deoxycholate, $0.5 \%$; Triton $\mathrm{X} 100,1 \%$; EDTA, $20 \mathrm{mM}$ (pH 7.2); dithiothreitol, $1 \mathrm{mM}$; protease inhibitor cocktail (Sigma-Aldrich)) and stored at $-80^{\circ} \mathrm{C}$ until further analyses. The amount of protein in the supernatant was determined by Bradford assay [34] and $40 \mu \mathrm{g}$ of protein per lane was separated by $10 \%$ SDS gel electrophoresis and transferred to polyvinylidenefluoride membranes, blocked for $1 \mathrm{~h}$ at room temperature in blocking buffer ( $5 \%$ bovine serum albumin (Sigma-Aldrich) in Tris-buffered saline Tween-20 (TBST: $0.8 \%(w / v)$ $\mathrm{NaCl}, 0.24 \%(w / v)$ Tris- $\mathrm{HCl}(\mathrm{pH} 7.6), 0.05 \%(v / v)$ Tween 20 in $\mathrm{H}_{2} \mathrm{O}_{\mathrm{dd}}$; Sigma-Aldrich, Taufkirchen, 
Germany)), and incubated with the primary antibodies (TTP (1:1000, ab155323); $\beta$-actin (1:1000, \#4967, Cell Signaling Technology, Danvers, USA)).

The primary antibodies were diluted in 5\% bovine serum albumin in TBST and incubated overnight at $4{ }^{\circ} \mathrm{C}$. Membranes were washed three times with TBST and incubated for $1 \mathrm{~h}$ at room temperature with the secondary antibody (goat anti-rabbit peroxidase conjugated (1:10,000, cat\#401353, Calbiochem/Merck Millipore, Darmstadt, Germany)). Membranes were washed three times with TBST and bands were visualized using AceGlow ${ }^{\mathrm{TM}}$ essential chemiluminescence solutions A and B (Peqlab Biotechnologie, Erlangen, Germany) and 20× LumiGLO ${ }^{\circledR}$ reagent and peroxide solutions (Cell Signaling Technology, Cambridge, UK). Intensities were recorded on a Fusion FX imaging system, and band intensities were quantified using FusionCapt Advance software (Vilber Lourmat, Eberhardzell, Germany). Expression of the protein $\alpha$-TTP was tested using the housekeeping protein $\beta$-actin as loading control.

\subsection{Statistical Analysis}

Statistical analyses were performed using GraphPad Prism 5 (GraphPad Software, San Diego, CA, USA). Differences between group means were calculated by one-way analysis of variance with a Tukey's multiple comparison test or by unpaired $t$-test with Welch's correction (heterogeneity of variances). Results are reported as means \pm standard error of the mean (SEM). Differences were considered significant at $p<0.05$.

Supplementary Materials: The following are available online. Figure S1: Representative GC/MS chromatograms (full scan mode) of the analyzed liver extracts of $\mathrm{TTP}^{+/+}$and $\mathrm{TTP}^{-/-}$mice fed a standard diet with either $\alpha$-tocopherol $\left(\alpha \mathrm{T}\right.$; A and B, respectively) or $\alpha-11^{\prime}$-tocomonoenol ( $\alpha \mathrm{T} 1 ; \mathrm{C}$ and $\mathrm{D}$, respectively) for 2 weeks. Figure S2: Mean concentrations of vitamin $\mathrm{E}$ in the diets used for breeding $(\mathrm{A})$, standard $(\mathrm{B})$ and experimental (C) diets fed the $\mathrm{TTP}^{+/+}$and $\mathrm{TTP}^{-/-}$mice during their life.

Author Contributions: Conceptualization, A.I.-M. and J.F.; methodology, J.F., A.I.-M., N.S., M.-L.H., and M.M.; validation, A.I.-M., N.S., M.-L.H., and M.M.; formal analysis, A.I.-M., N.S., and M.M.; investigation, A.I.-M., N.S., M.-L.H., and M.M.; resources, J.F. and W.V.; writing-original draft preparation, A.I.-M. and J.F.; writing-review and editing, J.F., A.I.-M., N.S., M.M., and W.V.; visualization, A.I.-M. and J.F.; supervision, A.I.-M. and J.F.; project administration, A.I.-M. and J.F.; funding acquisition, J.F. and A.I.-M. All authors have read and agreed to the published version of the manuscript.

Funding: This research was partially funded by the foundation fiat panis through a Dr. Hermann Eiselen Ph.D. grant within the framework of the Ph.D. Program "Global Food Security", which is organized by the Food Security Center of University of Hohenheim.

Acknowledgments: Andrea Irías-Mata acknowledges a scholarship provided by the Food Security Center of the University of Hohenheim, which is supported by the German Academic Exchange Service (DAAD) with funds of the Federal Ministry of Economic Cooperation and Development (BMZ) of Germany. The authors thank Alexander Montoya Arroyo (Institute of Nutritional Sciences, University of Hohenheim) for his kind help with the tissue sampling.

Conflicts of Interest: The authors declare no conflict of interest.

\section{References}

1. Galli, F.; Azzi, A.; Birringer, M.; Cook-Mills, J.M.; Eggersdorfer, M.; Frank, J.; Cruciani, G.; Lorkowski, S.; Özer, N.K. Vitamin E: Emerging aspects and new directions. Free Radic. Biol. Med. 2017, 102, 16-36. [CrossRef] [PubMed]

2. Matsumoto, A.; Takahashi, S.; Nakano, K.; Kijima, S. Identification of New Vitamin E in Plant Oil. J. Jpn. Oil Chem. Soc. 1995, 44, 593-597. [CrossRef]

3. Butinar, B.; Bučar-Miklavčič, M.; Mariani, C.; Raspor, P. New vitamin E isomers (gamma-tocomonoenol and alpha-tocomonoenol) in seeds, roasted seeds and roasted seed oil from the Slovenian pumpkin variety 'Slovenska golica'. Food Chem. 2011, 128, 505-512. [CrossRef] [PubMed]

4. Hammann, S.; Englert, M.; Müller, M.; Vetter, W. Accelerated separation of GC-amenable lipid classes in plant oils by countercurrent chromatography in the co-current mode. Anal. Bioanal. Chem. 2015, 407, 9019-9028. [CrossRef] 
5. Irías-Mata, A.; Stuetz, W.; Sus, N.; Hammann, S.; Gralla, K.; Cordero-Solano, A.; Vetter, W.; Frank, J. Tocopherols, Tocomonoenols, and Tocotrienols in Oils of Costa Rican Palm Fruits: A Comparison between Six Varieties and Chemical versus Mechanical Extraction. J. Agric. Food Chem. 2017, 65, 7476-7482. [CrossRef]

6. Schmölz, L.; Birringer, M.; Lorkowski, S.; Wallert, M. Complexity of vitamin E metabolism. World J. Biol. Chem. 2016, 7, 14-43. [CrossRef]

7. Grebenstein, N.; Schumacher, M.; Graeve, L.; Frank, J. $\alpha$-Tocopherol transfer protein is not required for the discrimination against $\gamma$-tocopherol in vivo but protects it from side-chain degradation in vitro. Mol. Nutr. Food Res. 2014, 58, 1052-1060. [CrossRef]

8. Hosomi, A.; Arita, M.; Sato, Y.; Kiyose, C.; Ueda, T.; Igarashi, O.; Arai, H.; Inoue, K. Affinity for $\alpha$-tocopherol transfer protein as a determinant of the biological activities of vitamin E analogs. FEBS Lett. 1997, 409, 105-108. [CrossRef]

9. Hosomi, A.; Goto, K.; Kondo, H.; Iwatsubo, T.; Yokota, T.; Arita, M.; Aoki, J.; Arai, H.; Inoue, K. Localization of a-tocopherol transfer protein in rat brain. Neurosci. Lett. 1998, 256, 159-162. [CrossRef]

10. Kaempf-Rotzoll, D.E.; Igarashi, K.; Aoki, J.; Jishage, K.; Suzuki, H.; Tamai, H.; Linderkamp, O.; Arai, H. $\alpha$-Tocopherol Transfer Protein Is Specifically Localized at the Implantation Site. Biol. Reprod. 2002, 67, 599-604. [CrossRef]

11. Yokota, T.; Shiojiri, T.; Gotoda, T.; Arita, M.; Arai, H.; Ohga, T.; Kanda, T.; Suzuki, J.; Imai, T.; Matsumoto, H.; et al. Friedreich-like ataxia with retinitis pigmentosa caused by the His101Gln mutation of the $\alpha$-Tocopherol transfer protein gene. Ann. Neurol. 1997, 41, 826-832. [CrossRef] [PubMed]

12. Ulatowski, L.; Manor, D. Vitamin E Trafficking in Neurologic Health and Disease. Annu. Rev. Nutr. 2013, 33, 87-103. [CrossRef] [PubMed]

13. Leonard, S.W.; Terasawa, Y.; Farese, R.V., Jr.; Traber, M.G. Incorporation of deuterated RRR- or all-rac- $\alpha$-tocopherol in plasma and tissues of $\alpha$-tocopherol transfer protein-null mice. Am. J. Clin. Nutr. 2002, 75, 555-560. [CrossRef] [PubMed]

14. Podda, M.; Weber, C.; Traber, M.G.; Packer, L. Simultaneous determination of tissue tocopherols, tocotrienols, ubiquinols, and ubiquinones. J. Lipid Res. 1996, 37, 893-901.

15. Khanna, S.; Patel, V.; Rink, C.; Roy, S.; Sen, C. Delivery of orally supplemented $\alpha$-tocotrienol to vital organs of rats and tocopherol-transport protein deficient mice. Free Radic. Biol. Med. 2005, 39, 1310-1319. [CrossRef]

16. Uchida, T.; Abe, C.; Nomura, S.; Ichikawa, T.; Ikeda, S. Tissue Distribution of $\alpha$ - and $\gamma$-Tocotrienol and $\gamma$-Tocopherol in Rats and Interference with Their Accumulation by $\alpha$-Tocopherol. Lipids 2012, 47, 129-139. [CrossRef]

17. Uchida, T.; Nomura, S.; Ichikawa, T.; Abe, C.; Ikeda, S. Tissue Distribution of Vitamin E Metabolites in Rats after Oral Administration of Tocopherol or Tocotrienol. J. Nutr. Sci. Vitaminol. 2011, 57, 326-332. [CrossRef]

18. Ikeda, S.; Tohyama, T.; Yoshimura, H.; Hamamura, K.; Abe, K.; Yamashita, K. Dietary alpha-tocopherol Decreases alpha-tocotrienol but not gamma-tocotrienol concentration in rats. J. Nutr. 2003, 133, 428-434. [CrossRef]

19. Eder, K.; Siebers, M.; Most, E.; Scheibe, S.; Weissmann, N.; Gessner, D.K. An excess dietary vitamin E concentration does not influence Nrf2 signaling in the liver of rats fed either soybean oil or salmon oil. Nutr. Metab. 2017, 14, 1-15. [CrossRef]

20. Lee, M.-J.; Feng, W.; Yang, L.; Chen, Y.-K.; Chi, E.; Liu, A.; Yang, C.S. Methods for efficient analysis of tocopherols, tocotrienols and their metabolites in animal samples with HPLC-EC. J. Food Drug Anal. 2018, 26, 318-329. [CrossRef]

21. Zhao, Y.; Lee, M.-J.; Cheung, C.; Ju, J.-H.; Chen, Y.-K.; Liu, B.; Hu, L.-Q.; Yang, C.S. Analysis of Multiple Metabolites of Tocopherols and Tocotrienols in Mice and Humans. J. Agric. Food Chem. 2010, 58, 4844-4852. [CrossRef] [PubMed]

22. Gohil, K.; Oommen, S.; Quach, H.T.; Vasu, V.T.; Aung, H.H.; Schock, B.; Cross, C.E.; Vatassery, G.T. Mice lacking $\alpha$-tocopherol transfer protein gene have severe $\alpha$-tocopherol deficiency in multiple regions of the central nervous system. Brain Res. 2008, 1201, 167-176. [CrossRef] [PubMed]

23. Gotoh, N.; Watanabe, H.; Oka, T.; Mashimo, D.; Noguchi, N.; Hata, K.; Wada, S. Dietary Marine-Derived Tocopherol has a Higher Biological Availability in Mice Relative to Alpha-Tocopherol. Lipids 2009, 44, 133-143. [CrossRef] [PubMed]

24. Birringer, M.; Pfluger, P.; Kluth, D.; Landes, N.; Brigelius-Flohé, R. Identities and Differences in the Metabolism of Tocotrienols and Tocopherols in HepG2 Cells. J. Nutr. 2002, 132, 3113-3118. [CrossRef] [PubMed] 
25. Uchida, T.; Nomura, S.; Sakuma, E.; Hanzawa, F.; Ikeda, S. $\alpha$-Tocopherol does not Accelerate Depletion of $\gamma$-Tocopherol and Tocotrienol or Excretion of their Metabolites in Rats. Lipids 2013, 48, 687-695. [CrossRef] [PubMed]

26. Behrens, W.A.; Madère, R. Kinetics of tissue RRR-alpha-tocopherol depletion and repletion. Effect of cold exposure. J. Nutr. Biochem. 1990, 1, 528-532. [CrossRef]

27. Beppu, F.; Kondo, H.; Kasatani, S.; Aoki, Y.; Gotoh, N. Quantitative Analysis of the Accumulation of Marine-derived Tocopherol in the Tissue of Mice Fed with Salmon Roe Oil Using HPLC-fluorescence. J. Oleo Sci. 2018, 67, 283-288. [CrossRef]

28. Liu, J.F.; Huang, C.J. Dietary oxidized frying oil enhances tissue alpha-tocopherol depletion and radioisotope tracer excretion in vitamin E-deficient rats. J. Nutr. 1996, 126, 2227-2235. [CrossRef]

29. Müller, M.; Hammann, S.; Vetter, W. Countercurrent chromatographic isolation and purification of $11^{\prime}-\alpha$-tocomonoenol from the vitamin E extract of palm oil. Food Chem. 2018, 256, 327-332. [CrossRef]

30. Fry, J.M.; Smith, G.M.; Mcgrath, M.C.; Speijers, E.J.; Allen, J.G. Plasma and tissue concentrations of $\alpha$-tocopherol during vitamin E depletion in sheep. Br. J. Nutr. 1993, 69, 225-232. [CrossRef]

31. Yoshida, Y.; Itoh, N.; Hayakawa, M.; Habuchi, Y.; Saito, Y.; Tsukamoto, Y.; Cynshi, O.; Jishage, K.; Arai, H.; Niki, E. The role of $\alpha$-tocopherol in motor hypofunction with aging in $\alpha$-tocopherol transfer protein knockout mice as assessed by oxidative stress biomarkers. J. Nutr. Biochem. 2010, 21, 66-76. [CrossRef] [PubMed]

32. Gaedicke, S.; Zhang, X.; Schmelzer, C.; Lou, Y.; Doering, F.; Frank, J.; Rimbach, G. Vitamin E dependent microRNA regulation in rat liver. FEBS Lett. 2008, 582, 3542-3546. [CrossRef] [PubMed]

33. Grebenstein, N.; Frank, J. Rapid baseline-separation of all eight tocopherols and tocotrienols by reversed-phase liquid-chromatography with a solid-core pentafluorophenyl column and their sensitive quantification in plasma and liver. J. Chromatogr. A 2012, 1243, 39-46. [CrossRef] [PubMed]

34. Bradford, M.M. A rapid and sensitive method for the quantitation of microgram quantities of protein utilizing the principle of protein-dye binding. Anal. Biochem. 1976, 72, 248-254. [CrossRef]

Sample Availability: Samples of the compounds are not available from the authors.

Publisher's Note: MDPI stays neutral with regard to jurisdictional claims in published maps and institutional affiliations.

(C) 2020 by the authors. Licensee MDPI, Basel, Switzerland. This article is an open access article distributed under the terms and conditions of the Creative Commons Attribution (CC BY) license (http://creativecommons.org/licenses/by/4.0/). 